\title{
Temperature dependent functional response of Diaeretiella rapae (Hymenoptera: Aphidiidae) to the cabbage aphid, Brevicoryne brassicae (Hemiptera: Aphididae)
}

\author{
HAmid R.S. MOAYERI ${ }^{1,2}$, Hossein MADADI ${ }^{3}$, Hossein POURASKARI ${ }^{1}$ and ANNIE ENKEGAARD ${ }^{4}$ \\ ${ }^{1}$ Department of Plant Protection, Faculty of Agriculture, Zanjan University, Iran; e-mail: Hamidsarrafm@gmail.com \\ ${ }^{2}$ Research Institute of Physiology and Biotechnology, Zanjan University, Iran; e-mail: Moayeri@ znu.ac.ir \\ ${ }^{3}$ Department of Plant Protection, Faculty of Agriculture, Bu-Ali Sina University, Iran; e-mail: hmadadi@basu.ac.ir \\ ${ }^{4}$ Department of Agroecology, Science and Technology, Aarhus University, Research Centre Flakkebjerg, 4200 Slagelse, Denmark; \\ e-mail: Annie.Enkegaard@agrsci.dk
}

Key words. Hymenoptera, Aphidiidae, Diaeretiella rapae, Hemiptera, Aphididae, Brevicoryne brassicae, searching, handling time, functional response, biological control

\begin{abstract}
Diaeretiella rapae MacIntosh (Hymenoptera: Aphidiidae) is one of the most common and successful parasitoids of the cabbage aphid. The functional response of $D$. rapae towards cabbage aphids was examined in laboratory studies at three constant temperatures, $17^{\circ} \mathrm{C}, 25^{\circ} \mathrm{C}$ and $30^{\circ} \mathrm{C}$. D. rapae exhibited a type II functional response at all three temperatures. The search rates were uninfluenced by temperature whereas handling times differed significantly between $17^{\circ} \mathrm{C}$ and $25^{\circ} \mathrm{C}$, and between $17^{\circ} \mathrm{C}$ and $30^{\circ} \mathrm{C}$, but not between $25^{\circ} \mathrm{C}$ and $30^{\circ} \mathrm{C}$. This study is a first-step in the evaluation of the effectiveness of $D$. rapae as a biocontrol agent of Brevicoryne brassicae at different temperatures.
\end{abstract}

\section{INTRODUCTION}

The cabbage aphid, Brevicoryne brassicae (Linneaus) (Hemiptera: Aphididae) is a serious cosmopolitan pest, attacking many cruciferous crops, such as broccoli, canola, cabbage, cauliflower and mustard (Blackman \& Eastop, 2000; Capinera, 2001; Modarres Najafabadi et al., 2005; Desneux et al., 2006). This pest can cause direct damage by inducing plant deformations (Oatman \& Planter, 1969) and by stunting or killing young plants (Bonnemaison, 1965; Ellis et al., 1998; Ulusoy \& Bayhan, 2006). In addition, it can also induce indirect damage by transmitting more than 20 different viruses including yellow mosaic virus, cucumber mosaic virus, onion yellow dwarf virus and cabbage black ring spot (Ellis et al., 1998; Blackman \& Eastop, 2000).

Considering the difficulties associated with aphid control there is one environmentally safe control method, which is to use natural enemies, especially parasitoids. Diaeretiella rapae MacIntosh (Hymenoptera: Aphidiidae) is reported to be an important and promising endoparasitoid of more than 60 aphid species, including the cabbage aphid (Hagvar \& Hofsvang, 1991), green peach aphid [Myzus persicae (Sulzer)] (Stark \& Acheampong, 2007) and Russian wheat aphid [Diuraphis noxia (Mordvilko)] (Stary, 1999; Rakhshani et al., 2008).

Evaluation of the changes that occur in the characteristics and efficiency of candidate biocontrol agents with changes in environmental factors is crucial for their successful use in biocontrol programs. The response of a natural enemy to increasing host density (functional response) is important for the outcome of parasitoid- based biocontrol programs (Berryman, 2004) and together with the numerical response an indispensable element in their biological characterization (Cedola et al., 2001, Gilioli et al., 2005) and an important determinant of their effectiveness as biological control agents (Houck \& Strauss, 1985; Jost \& Ellner, 2000). Different factors may influence their functional responses, including host plant surface traits (Coll \& Ridgway, 1995; Messina \& Hanks, 1998; Madadi et al., 2007), host species (Mansfield \& Mills, 2004), natural enemy life stages (Seko \& Miura, 2008), host age (King, 1994; Ode \& Strand, 1995) and spatial complexity (Madadi et al., 2011). However, the functional response of poikilothermic organisms like parasitoids, are greatly affected by temperature (Cave \& Gaylor, 1989; Flinn, 1991; Enkegaard, 1994; Bazzocchi \& Burgio, 2001; Jones et al., 2003; Kalyebi et al., 2005; Shojaei et al., 2006; Moezipour et al., 2008; Tazerouni et al., 2012).

The functional response of $D$. rapae to the cabbage aphid has been studied (e.g. Fathipour et al., 2006) but no one has considered the effect of temperature. Consequently, the aim of this study was to determine the influence of temperature on the searching efficiency and handling time of $D$. rapae attacking cabbage aphid nymphs.

\section{MATERIAL AND METHODS}

\section{Insect rearing}

Cabbage aphids and D. rapae were originally collected from infested ornamental cabbage, Brassica oleracea L. (var. acephala), on the Zanjan University campus in October 2010 and subsequently kept in separate cultures on $B$. oleracea in net covered cages $(40 \times 40 \times 40 \mathrm{~cm})$ at $24 \pm 2^{\circ} \mathrm{C}, 45 \pm 5 \%$ R.H. and a photo- 
period of $16 \mathrm{~L}: 8 \mathrm{D}$ in the Insect Ecology and Biocontrol Laboratory, the Research Institute of Physiology and Biotechnology, Zanjan University.

\section{Functional response experiments}

Mummified cabbage aphids were collected from the colony and placed individually in small vials (approx. $4 \mathrm{ml}$ ). After $24 \mathrm{~h}$, newly emerged parasitoids were removed and placed in plexiglas cylindrical cages $(15 \times 35 \mathrm{~cm})$ and fed a $10 \%$ honey solution. Twenty four hours later mated females were recovered and kept individually in similar small vials for $2-3 \mathrm{~h}$ before using them in the experiments.

The experimental arena consisted of a cabbage leaf placed in a Petri dish ( $9 \mathrm{~cm}$ diameter) with two droplets of honey and a piece of wet cotton wool added as food and a source of water. Two, 4, 6, 8, 16, 24, 40 or 50 second instar nymphs of $B$. brassicae were placed randomly on the leaf. The number of replicates was 15 except for the density 8 nymphs per leaf at $17^{\circ} \mathrm{C}$ and 50 at $30^{\circ} \mathrm{C}$, for which there were 14 replicates. One female D. rapae was added to each arena, which was then placed in a growth chamber at 17,25 or $30^{\circ} \mathrm{C}, 65 \pm 5 \%$ R.H. and a photoperiod of $16 \mathrm{~L}: 8 \mathrm{D}$. After $24 \mathrm{~h}$ the parasitoids were removed and the arenas were kept in the same conditions for a further 2 weeks after which the numbers of mummified aphids were recorded. The present study thus only examines the influence of temperature on the functional response in terms of the parasitization activity of the adult parasitoids. All replicates at each temperature were conducted simultaneously over a 3-week period.

\section{Statistical analysis}

The overall effect of temperature on the rate of parasitization of $B$. brassicae by D. rapae was analysed by comparing the number of mummified aphids recorded at the different temperatures (one-way ANOVA or Kruskal-Wallis test, SAS Institute Inc. 2004).

Subsequently, the type of functional response and the parameters characterizing it were estimated for each temperature (Juliano, 2001). Logistic regressions of the proportions of aphids parasitized at different host densities were used to determine the type of functional response (Trexler et al., 1988; Trexler \& Travis, 1993) using the quadratic model:

$$
\text { (1) } \frac{N_{e}}{N_{0}}=\frac{\exp \left(P_{0}+P_{1} N_{0}+P_{2} N_{0}^{2}\right)}{1+\exp \left(P_{0}+P_{1} N_{0}+P_{2} N_{0}^{2}\right)}
$$

where $N_{e}$ is the number of parasitized aphids, $N_{0}$ is the host density and $P_{0}, P_{1}$ and $P_{2}$ are the parameters to be estimated. Significant negative values of $P_{1}$ indicate a type II functional response, whereas positive significant values indicate a type III functional response (Juliano, 2001).

Non-linear least-square regression (NLIN procedure, SAS Institute Inc., 2004) of the number of mummified aphids recorded at different host densities was used for estimating searching rates and handling times (Juliano \& Williams, 1987; Juliano, 2001) based on either the Random Parasitoid Equation (Rogers, 1972) (Equation 2), or if that failed to provide an adequate fit or meaningful parameter estimates, Holling's Disc Equation (Holling, 1961) (Equation 3).

(2) Roger's model $N_{e}=N_{0}\left\{1-\exp \left[-\frac{a T}{1+a T_{h} N_{0}}\right]\right\}$

(3) Holling's Disc Equation $N_{e}=\frac{a N_{0} T}{\left(1+a N_{0} T_{h}\right)}$

Where $a$ is the search rate, $T$ the total available time (here $24 \mathrm{~h}$ ) and $T_{h}$ the handling time (Juliano \& Williams, 1987; Juliano, 2001). The individual parameters for each pair of temperatures were compared using $t$-tests (SAS/STAT, NLMIXED, SAS Institute Inc., 2004).
TABLE 1. Mean ( \pm SE) number Brevicoryne brassicae nymphs parasitized by Diaeretiella rapae at different temperatures.

\begin{tabular}{cccc}
\hline Density & $17^{\circ} \mathrm{C}$ & $25^{\circ} \mathrm{C}$ & $30^{\circ} \mathrm{C}$ \\
\hline 2 & $1.44 \pm 0.16 \mathrm{~A}$ & $1.56 \pm 0.13 \mathrm{~A}$ & $1.50 \pm 0.13 \mathrm{~A}$ \\
4 & $2.56 \pm 0.25 \mathrm{~A}$ & $3.06 \pm 0.27 \mathrm{~A}$ & $2.88 \pm 0.26 \mathrm{~A}$ \\
6 & $4.07 \pm 0.36 \mathrm{~A}$ & $4.50 \pm 0.42 \mathrm{~A}$ & $4.27 \pm 0.42 \mathrm{~A}$ \\
8 & $5.14 \pm 0.41 \mathrm{~A}$ & $5.94 \pm 0.32 \mathrm{~A}$ & $5.88 \pm 0.42 \mathrm{~A}$ \\
16 & $6.81 \pm 0.67 \mathrm{~A}$ & $8.19 \pm 0.56 \mathrm{~A}$ & $7.87 \pm 0.54 \mathrm{~A}$ \\
24 & $7.73 \pm 0.82 \mathrm{~A}$ & $10.44 \pm 0.7 \mathrm{~B}$ & $9.94 \pm 0.7 \mathrm{AB}$ \\
40 & $10.4 \pm 0.89 \mathrm{~A}$ & $14.13 \pm 1.22 \mathrm{~B}$ & $13.13 \pm 1.03 \mathrm{AB}$ \\
50 & $10.93 \pm 0.88 \mathrm{~A}$ & $15.8 \pm 1.17 \mathrm{~B}$ & $13.64 \pm 1.2 \mathrm{AB}$ \\
\hline
\end{tabular}

Different letters in a row $(\mathrm{A}, \mathrm{B})$ indicate significant differences between different temperatures, $\mathrm{P}<0.05$.

\section{RESULTS}

The effect of temperature on the mean number of cabbage aphid nymphs parasitized by $D$. rapae was apparent only at the higher host densities (Table 1). Temperature, cabbage aphid density and their interaction had a significant effect on the number of nymphs parasitized (GLM $17^{\circ} \mathrm{C}$, df $=2,334, \mathrm{~F}=14.89, \mathrm{P}<0.0001 ; \mathrm{GLM} 25^{\circ} \mathrm{C}$, df $=7,334, \mathrm{~F}=129.5, \mathrm{P}<0.0001$ and $\mathrm{GLM} 30^{\circ} \mathrm{C}$, $\mathrm{df}=14$, $334, \mathrm{~F}=1.84, \mathrm{P}=0.032$, respectively) (Table 1 ).

Temperature did not affect the type of functional response recorded for $D$. rapae as the linear term of the logistic regression in all cases was significantly negative, i.e. the number of cabbage aphids parasitized increased with a decreasing slope, which indicates a type II functional response (Table 2, Fig. 1).

Roger's Random Parasitoid Equation (Rogers, 1972) did not fit the data and the functional response parameters were consequently estimated using Holling's Disc Equation (Holling, 1961) (Table 3). The search rates were not influenced by temperature (t-test, $17^{\circ} \mathrm{C}$ vs. $25^{\circ} \mathrm{C}, \mathrm{t}=$ $-0.152, P=0.879 ; 17^{\circ} \mathrm{C}$ vs. $30^{\circ} \mathrm{C}: t=-0.243, P=0.809$; $25^{\circ} \mathrm{C}$ vs. $\left.30^{\circ} \mathrm{C}: t=-0.098, P=0.922\right)$ whereas handling times recorded at $17^{\circ} \mathrm{C}$ and $25^{\circ} \mathrm{C}$ and at $17^{\circ} \mathrm{C}$ and $30^{\circ} \mathrm{C}$ differed significantly, but not at $25^{\circ} \mathrm{C}$ and $30^{\circ} \mathrm{C}\left(17^{\circ} \mathrm{C}\right.$ vs. $25^{\circ} \mathrm{C}: t=3.876, P<0.001 ; 17^{\circ} \mathrm{C}$ vs. $30^{\circ} \mathrm{C}: t=2.762, P=$ $0.006 ; 25^{\circ} \mathrm{C}$ vs. $\left.30^{\circ} \mathrm{C}: t=-1.138, P=0.256\right)$. The maximum attack rates $\left(\mathrm{T} / \mathrm{T}_{\mathrm{h}}\right)$ were $14.54,24.74$ and 20

TABLE 2. Logistic regression analysis of the proportion of Brevicoryne brassicae nymphs parasitized by Diaeretiella rapae at different host densities at different temperatures.

\begin{tabular}{cccccc}
\hline Temp. & Parameter & Estimate & SE & $\chi^{2}$ value & Pvalue \\
\hline $17^{\circ} \mathrm{C}$ & Constant & 1.107 & 0.179 & 38.32 & $<.0001$ \\
& Linear & -0.095 & 0.015 & 41.84 & $<.0001$ \\
& Quadratic & 0.001 & 0.0002 & 15.48 & $<.0001$ \\
$25^{\circ} \mathrm{C}$ & Constant & 1.46 & 0.185 & 62.5 & $<.0001$ \\
& Linear & -0.093 & 0.014 & 41.06 & $<.0001$ \\
& Quadratic & 0.001 & 0.0002 & 16.87 & $<.0001$ \\
$30^{\circ} \mathrm{C}$ & Constant & 1.347 & 0.183 & 54.39 & $<.0001$ \\
& Linear & -0.089 & 0.0143 & 37.35 & $<.0001$ \\
& Quadratic & 0.0009 & 0.0002 & 12.85 & 0.0003 \\
\hline
\end{tabular}




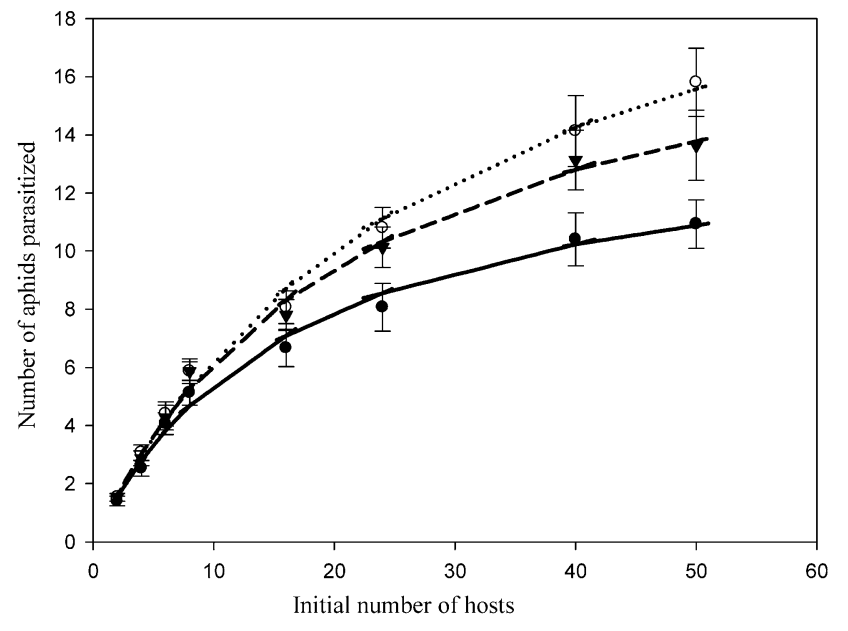

Fig. 1. Functional response of Diaeretiella rapae to Brevicoryne brassicae nymphs at $17^{\circ} \mathrm{C}$ (solid line, black circles), $25^{\circ} \mathrm{C}$ (dotted line, white circles) and $30^{\circ} \mathrm{C}$ (dashed line, black triangles). The symbols represent average values (with standard errors) and the lines the fitted model.

second instar aphid nymphs per day at $17^{\circ} \mathrm{C}, 25^{\circ} \mathrm{C}$ and $30^{\circ} \mathrm{C}$, respectively.

\section{DISCUSSION}

D. rapae showed a type II functional response to increasing densities of cabbage aphid nymphs at all the temperatures tested. Type II functional responses are commonly recorded for parasitoids, especially under controlled conditions in the laboratory (Fernandez-Arhex \& Corley, 2003). In fact, more than three quarters of such studies carried out on parasitoids between 1959-2001 report type II functional responses (Fernandez-Arhex \& Corley, 2003). This may be due to the generally artificial experimental design in which parasitoids have a fixed time to search for hosts and there is a lack of any spatial complexity within patches (Fernandez-Arhex \& Corley, 2003).

A type II functional response of D. rapae is reported for the cabbage aphid (Fathipour et al., 2006), Russian wheat aphid (Bernal et al., 1994; Tazerouni et al., 2011, 2012) and green peach aphid (Yu et al., 1993). The rate at which this parasitoid attacks cabbage and green peach aphids is estimated to be $0.033 \mathrm{~h}^{-1}$ (Fathipour et al., 2006) and $0.031 \mathrm{~h}^{-1}$ (Yu et al., 1993), respectively, which is in accordance with our results, whereas the rate at which it attacks the Russian wheat aphid is higher $\left(0.056 \mathrm{~h}^{-1}\right.$ (Bernal et al., 1994) and $0.072 \mathrm{~h}^{-1}$ (Tazerouni et al., 2011), respectively). These higher rates of attack might be due to the differences in the sizes of the hosts, as the Russian wheat aphid is smaller than the cabbage aphid (Antolin et al., 2006), and handling time in aphid parasitoids is thought to be inversely related to host size (Hofsvang \& Hagvar, 1986).

Temperature had a significant effect on the number of cabbage aphids parasitized by $D$. rapae only at the higher cabbage aphid densities, which is reflected in the significantly higher handling time recorded at the lowest temperature. No influence of temperature on attack rate was
TABLE 3. Parameter estimates (mean $\pm \mathrm{SE}$ ) and $\mathrm{R}^{2}$ values of the functional response of Diaretiella rapae parasitizing Brevicoryne brassicae nymphs estimated using the Disc Equation. Values in square brackets are $95 \%$ confidence limits.

\begin{tabular}{cccc}
\hline Temperatures & $\mathrm{a}^{\prime}\left(\mathrm{h}^{-1}\right)$ & $\mathrm{T}_{\mathrm{h}}(\mathrm{h})$ & $\mathrm{R}^{2}$ \\
\hline \multirow{2}{*}{$17^{\circ} \mathrm{C}$} & $0.036 \pm 0.004$ & $1.65 \pm 0.14$ & \multirow{2}{*}{0.66} \\
& {$[0.027 ; 0.045]$} & {$[1.38 ; 1.93]$} & \\
$25^{\circ} \mathrm{C}$ & $0.035 \pm 0.004$ & $0.97 \pm 0.095$ & 0.77 \\
& {$[0.028 ; 0.042]$} & {$[0.78 ; 1.16]$} & \\
30 & $0.037 \pm 0.004$ & $1.2 \pm 0.104$ & 0.74 \\
& {$[0.029 ; 0.045]$} & {$[0.99 ; 1.41]$} & \\
\hline
\end{tabular}

found. The longer handling time recorded at $17^{\circ} \mathrm{C}$ is most likely a result of an increase in non-searching activities (e.g. resting). A similar temperature-dependent influence on functional response parameters with a decrease in handling time with increase in temperature without significant effects on search rates is recorded for predators, e.g. the predatory mite Neoseiulus californicus (McGregor) attacking Tetranychus urticae Koch (Ahn et al., 2009). Considering the effect of global warming and climate change, the effect temperature has on the handling time of $D$. rapae indicates that this parasitoid performs best at temperatures around $25^{\circ} \mathrm{C}$ and it is likely to be less effective at higher temperatures.

Compared with the parasitization of other aphid species by $D$. rapae, such as D. noxia, M. persicae and Lipaphis erysimi (Kaltenbach), the parasitization of cabbage aphids in the present study was slightly higher than that recorded for D. noxia (Tazerouni et al., 2012) and lower than for the other two species (Blande et al., 2004). The highest number of aphids parasitized by $D$. rapae in the present study was $15.8 \pm 1.17$ at the density of 50 at $25^{\circ} \mathrm{C}$ (Table 1), which is slightly lower than recorded by Fathipour et al. (2006) (17.3 \pm 0.87$)$ for the same host-parasitoid system at a similar temperature and host density. This discrepancy may be due to differences in the parasitoid biotypes or size of experimental arena used.

The results of the present research indicate that $D$. rapae can be used as a biocontrol agent of B. brassicae and probably other aphid species, such as the green peach aphid, at temperatures ranging between 17 and $30^{\circ} \mathrm{C}$. However, for a comprehensive evaluation of the effectiveness of $D$. rapae in controlling cabbage aphids infesting other host plants more natural and field-based studies are needed (Bernal et al., 1994; Montoya et al., 2000). The present results additionally provide a basis for using $D$. rapae for augmentative or conservational biocontrol using the banker plant method (Huang et al., 2011) by developing a system consisting of crop or noncrop plants infested with a specialist crucifer-feeding aphid species as a non-pest alternative prey.

ACKNOWLEDGEMENT. The authors are grateful to H.A. Lotfalizadeh, Department of Plant Protection, East Azerbaijan Research Centre for Agriculture and Natural Resources, Tabriz, Iran for identifying $D$. rapae. 


\section{REFERENCES}

AhN J.J., Kim W.K. \& Lee J.H. 2009: Functional response of Neoseiulus californicus (Acari: Phytoseiidae) to Tetranychus urticae (Acari: Tetranychidae) on strawberry leaves. - J. Appl. Entomol. 134: 98-104.

Antolin M.F., Buorksten T.A. \& Vaughn T.T. 2006: Hostrelated fitness trade-offs in a presumed generalist parasitoid, Diaeretiella rapae (Hymenoptera: Aphidiidae). - Ecol. Entomol. 31: 242-254.

Bazzocchi G.G. \& Burgio G. 2001: Functional response of Lysiphlebus testaceipes (Cresson) (Hymenoptera: Braconidae) against Aphis gossypii Glover (Homoptera: Aphelinidae) at two constant temperatures. - Bull. Insectol. 54: 13-21.

Bernal J.S., Bellows T.S. \& Gonzalez D. 1994: Functional response of Diaeretiella rapae (McIntosch) (Hym.: Aphidiidae) to Diuraphis noxia (Mordvilko) (Hom., Aphididae) hosts. - J. Appl. Entomol. 118: 300-309.

BerRyman A.A. 2004: The theoretical foundations of biological control. In Hawkins B.A. \& Cornell H.V. (eds): Theoretical Approaches to Biological Control. Cambridge University Press, Cambridge, pp. 3-21.

Blackman R.L. \& EAstop V.F. 2000: Aphids of the World's Crops: An Identification and Information Guide. 2nd ed. John Wiley and Sons, London, $466 \mathrm{pp}$.

Blande J.D., Pickett J.A. \& Poppy G.M. 2004: Attack rate and success of the parasitoid Diaeretiella rapae on specialist and generalist feeding aphids. - J. Chem. Ecol. 30: 1781-1795.

BonNEMAISON L. 1965: Insect pests of crucifers and their control. - Annu. Rev. Entomol. 10: 230-256.

Capinera J.L. 2001: Handbook of Vegetable Pests. Academic Press, San Diego, 729 pp.

Cave R.D. \& GaYlor M.J. 1989: Functional response of Telenomus reynoldsi (Hym.: Scelionidae) at five constant temperatures and in an artificial plant arena. - Entomophaga 34: $3-10$.

Cedola C.V., Sanchez N.E. \& Liljesthrom G.G. 2001: Effect of tomato leaf hairiness on functional and numerical response of Neoseiulus californicus (Acari: Phytoseiidae). - Exp. Appl. Acarol. 25: 819-831.

Coll M. \& Ridgway R.L. 1995: Functional and numerical response of Orius insidious (Heteroptera: Anthocoridae) to its prey in different vegetable crops. - Ann. Entomol. Soc. Am. 88: $732-738$.

Desneux N., Rabasse J.M., Ballanger Y. \& Kaiser L. 2006 Parasitism of canola aphids in France in autumn. - J. Pest Sci. 79: 95-102.

Ellis P.R., Pink D.A.C., Phleps K., Breeds S.E. \& Pinnegar A.E. 1998: Evaluation of a core collection of Brassica oleracea accessions for resistance to Brevicoryne brassicae, the cabbage aphid. - Euphytica 103: 149-160.

ENKEGAARD A. 1994: Temperature dependent functional response of Encarsia formosa parasitizing the poinsettiastrain of the cotton whitely, Bemisia tabaci, on poinsettia. Entomol. Exp. Appl. 73: 19-29.

Fathipour Y., Hosseini A., Talebi A.A. \& Moharramipour S. 2006: Functional response and mutual interference of Diaeretiella rapae (Hymenoptera: Aphidiidae) on Brevicoryne brassicae (Homoptera: Aphididae). — Entomol. Fenn. 17: 90-97.

Fernandez-ArheX V. \& Corley J.C. 2003: The functional response of parasitoids and its implications for biological control. - Biocontr. Sci. Tech. 13: 403-413.

FLINN P.W. 1991: Temperature-dependent functional response of the parasitoid Cephalonomia watersoni (Gahan) (Hymenoptera: Bethylidae) attacking rusty grain beetle larvae (Coleoptera: Cucujidae). - Environ. Entomol. 20: 872-876.
Gilioli G., Baumgartner J. \& Vacante V. 2005: Temperature influences on functional response of Coenosia attenuata (Diptera: Muscidae) individuals. - J. Econ. Entomol. 98: $1524-1530$

Hagvar E.B. \& Hofsvang T. 1991: Aphid parasitoids (Hymenoptera, Aphidiidae): biology, host selection and use in biological control. - Biocont. News Info. 12: 13-41.

Hofsvang B. \& Hagvar E. 1986: Oviposition behaviour of Ephedrus cerasicola (Hym.: Aphidiidae) parasitizing different instars of its aphid host. - BioControl 31: 261-267.

Holling C.S. 1961: Principles of insect predation. - Annu. Rev. Entomol. 6: 163-182.

Houck M. \& Strauss R.E. 1985: The comparative study of functional responses: experimental design and statistical interpretation. - Can. Entomol. 117: 617-629.

Huang N., Enkegaard A., Osborne L.S., Ramakers P.M.J., Messelink G.J., Pijnakker J. \& Murphy G. 2011: The banker plant method in biological control. - Crit. Rev. Plant Sci. 30: 259-278.

Jones D.B., Giles K.L., Berberet R.C., Royer T.A., Elliot N.C. \& PAYton M.E. 2003: Functional response of an introduced parasitoid and an indigenous parasitoid on green bug at four temperatures. - Environ. Entomol. 32: 425-432.

Jost C. \& Ellner S.P. 2000: Testing for predator dependence in predator-prey dynamics: a non-parametric approach. - Proc. R. Soc. Lond. 267: 1611-1620.

JULIANO S.A. 2001: Nonlinear curve fitting: predation and functional response curves. In Scheiner S. \& Gurevitch J. (eds): Design and Analysis of Ecological Experiments. 2nd ed. Chapman \& Hall, New York, pp. 178-196.

Juliano S.A. \& Williams F.M. 1987: A comparison of methods for estimating the functional response parameters of the random predator equation. - J. Anim. Ecol. 56: 563-641.

Kalyebi A., Overholt W.A., Schulthess F., Mueke J.M., Hassan S.A. \& Sithanantham S. 2005: Functional response of six indigenous trichogrammatid egg parasitoids (Hymenoptera: Trichogrammatidae) in Kenya: influence of temperature and relative humidity. - Biol. Contr. 32: 164-171.

King B.H. 1994: How do female parasitoid wasps assess host size during sex-ratio manipulation. - Anim. Behav. 48: 511-518.

Madadi H., Enkegaard A., Brodsgaard H.F., Kharrazi-Pakdel A., Ashouri A. \& Mohaghegh-Neishabouri J. 2007: Host plant effects on the functional response of Neoseiulus cucumeris to onion thrips larvae. - J. Appl. Entomol. 131: 728-733.

Madadi H., Mohajeri Parizi E., Allahyari H. \& Enkegaard A. 2011: Assessment of the biological control capability of Hippodamia variegata (Col.: Coccinellidae) using functional response experiments. - J. Pest Sci. 84: 447-455.

MANSFIELD S. \& Mills N.J. 2004: A comparison of methodologies for the assessment of host preference of the gregarious egg parasitoid Trichogramma platneri. - Biol. Contr. 29: 332-340.

Messina F.J. \& Hanks J.B. 1998: Host plant alters the shape of the functional response of an aphid predator (Coleoptera: Coccinellidae). - Environ. Entomol. 27: 1196-1202.

Modarres Najafabadi S.S., Akbari Moghaddam H. \& GHoLAMIAN G.H. 2005: Population fluctuations of cabbage aphid (Brevicoryne brassicae) and identification of its natural enemies in Sistan region. - J. Crop Prod. Process. 8: 175-184 [in Persian with English abstr.].

Moezipour M., Kafil M. \& Allahyari H. 2008: Functional response of Trichogramma brassicae at different temperatures and relative humidities. - Bull. Insectol. 61: 245-250. 
Montoya P., Liedo P., Benery B., Barrere J.F., Cancino J. \& Aluja M. 2000: Functional response and superparasitism by Diachasmimoopha longicaudata (Hymenoptera: Braconidae), a parasitoid of fruit flies (Diptera: Tephritidae). — Ann. Entomol. Soc. Am. 93: 47-54.

Oatman E.R. \& Platner G.R. 1969: An ecological study of insect populations on cabbage in southern California. - Hilgardia 40: $1-40$.

Ode P.J. \& Strand M.R. 1995: Progeny and sex allocation decisions of the polyembryonic wasp Copidosoma floridanum. J. Anim. Ecol. 64: 213-224.

Rakhshani E., Tomanovic Z., Stary P., Talebi A.A., Kavalieratos N.G., Zamani A.A. \& Stemankovic S. 2008: Distribution and diversity of wheat aphid parasitoids (Hymenoptera: Braconidae: Aphidiinae) in Iran. - Eur. J. Entomol. 105: 863-870.

Rogers D. 1972: Random predator search and insect population models. - J. Anim. Ecol. 41: 369-383.

SAS Institute Inc. 2004: SAS/STAT User's Guide, Version 9.1, Vols 1 and 2. SAS Institute Inc., Cray.

Seko T. \& Miura K. 2008: Functional response of the lady beetle Harmonia axyridis (Pallas) (Coleoptera: Coccinellidae) on the aphid Myzus persicae (Sulzer) (Homoptera: Aphididae). - Appl. Entomol. Zool. 43: 341-345.

Shojaei S., Safaralizadeh M.H. \& Shayesteh N. 2006: Effect of temperature on the functional response of Habrobracon hebetor Say (Hymenoptera: Braconidae) to various densities of the host, Plodia interpunctella Hubner (Lepidoptera: Pyralidae). - Pak. Entomol. 28: 51-55.

StARK J.D. \& ACheAmPong S. 2007: A demographic and modelling approach to determine the suitability of two hosts,
Brevicoryne brassicae (Linneaus) and Myzus persicae (Sulzer) Heteroptera: Aphididae) of the aphid parasitoid, Diaeretiella rapae (McIntosch) (Hymenoptera: Aphidiidae). - Pan-Pacific Entomol. 83: 75-79.

STARY P. 1999: Parasitoids and biocontrol of Russian wheat aphid, Diuraphis noxia (Kurdj.) expanding in central Europe. — J. Appl. Entomol. 123: 273-279.

Tazerouni Z., Talebi A.A. \& Rakhshani E. 2011: The foraging behaviour of Diaeretiella rapae (Hymenoptera: Braconidae) on Diuraphis noxia (Hemiptera: Aphididae). — Acta Biol. Sci. 63: 225-234.

Tazerouni Z., TAlebi A.A. \& Rakhshani E. 2012: Temperaturedependent functional response Diaeretiella rapae (Hymenoptera: Braconidae) a parasitoid of Diuraphis noxia (Hemiptera: Aphididae). - J. Entomol. Res. Soc. 14(1): $31-40$.

TreXler J.C. \& Travis J. 1993: Nontraditional regression analysis. - Ecology 74: 1629-1637.

Trexler J.C., McCulloch C.E. \& Travis J. 1988: How can the functional response best be determined? - Oecologia 76: 206-214.

Ulusoy M.R. \& BAYHAN S.O. 2006: Effect of certain Brassica plants on biology of the cabbage aphid Brevicoryne brassicae under laboratory conditions. - Phytoparasitica 34: 133-138.

YU M.G., GU D.J. \& ZHANG W.Q. 1993: The effects of temperatures on the foraging behaviour of parasitoid Diaeretiella rapae (Hym.: Braconidae). - J. South China Agric. Univ. 14: $20-25$.

Received May 2, 2012; revised and accepted July 11, 2012 